\title{
First-year university students entrepreneurial competence: Exploring the relationship between grit, creative self-efficacy and entrepreneurial self-efficacy
}

\author{
Paula Álvarez-Huerta ${ }^{1}$, Iñaki Larrea ${ }^{1}$, Alexander Muela ${ }^{2}$ \\ ${ }^{1}$ Innovation and Intervention in Inclusive Education, Mondragon Unibertsitatea, Spain, \\ ${ }^{2}$ Department of Clinical and Health Psychology and Research Methodology, University of \\ the Basque Country, Spain.
}

\begin{abstract}
Grit, creative self-efficacy and entrepreneurial self-efficacy have been associated with the development of entrepreneurial behaviours that can prepare students for a rapidly changing world of work. The main purpose of this study is to analyse the relationship between the three variables amongst first-year university students. A positive relationship, albeit modest, was found between grit and the two measures of self-efficacy. Furthermore, findings suggest that grit can be considered a predictor variable for student self-efficacy beliefs in the context of entrepreneurship. However, this relationship was found to be weak and not to offer significant opportunities for the improvement of student creative and entrepreneurial self-perception, beyond those already contemplated in social cognitive theory. Moreover, results revealed a significant and robust positive relationship between creative and entrepreneurial self-perceptions in university students. The strong relationship found between creative and entrepreneurial self-efficacy renders an opportunity to develop informed interventions directed towards improving student entrepreneurial self-perceptions. In this regard, the results suggest the importance of cultivating creativity in educational institutions.
\end{abstract}

Keywords: Creative self-efficacy; entrepreneurial self-efficacy; grit; consistency of interest; perseverance of effort; entrepreneurship. 


\section{Introduction}

Entrepreneurship is widely recognised as an essential engine of economic and social development (Ribeiro-Soriano, 2017). The importance of entrepreneurship has been particularly highlighted in the face of the worldwide COVID-19 pandemic, which has exposed the world to great uncertainty (Etemad, 2020). Given its relevance, there is considerable interest in the study of the variables that influence the development of entrepreneurial competence (Barba-Sánchez \& Atienza-Sahuquillo, 2018; Newman et al., 2018).

Entrepreneurship is fraught with difficulties and uncertainties that require differentiated skills (Lopez-Ñunez et al., 2020). In this regard, research has found that self-regulation processes play a key role in entrepreneurial competence (Gielnik et al., 2020). Among these regulatory processes, the role of self-efficacy has been highlighted. According to social cognitive theory, self-efficacy is a motivational mechanism that promotes the development and achievement of objectives. It has been defined as having confidence in one's own abilities to organize and execute courses of action to bring about certain achievements (Bandura, 1997). Self-efficacy is not a global trait but rather a set of beliefs regarding the ability to perform tasks in specific domains (Bandura, 2006). Of particular relevance in entrepreneurship is entrepreneurial self-efficacy, which has been associated with greater entrepreneurial intentions (Newman et al., 2018). In addition, there is growing theoretical and empirical work that asserts the importance of creative self-efficacy in the development of an entrepreneurial career (Fuller et al., 2018).

Another self-regulatory process that has recently generated attention in the field of entrepreneurship is grit (Salisu et al., 2020). Grit has been defined as the inclination to maintain interest and strive toward meaningful and challenging personal goals (Duckworth et al., 2007). Thus, two components distinguish the construct of grit: perseverance of effort and consistency of interests (Duckworth et al., 2007). Recent evidence suggests that grit facilitates entrepreneurial action (Salisu et al., 2020).

The need to investigate the relationship between self-efficacy and trait-like personality variables like grit has been indicated (Stajkovic et al., 2018). According to Bandura (1997), self-efficacy not only affects the choices people make, but also their perseverance. From this perspective, there is evidence that indicates that self-efficacy partially or fully mediates the relationship between grit and academic outcomes (Usher et al., 2019). Nonetheless, other authors such as Wolters \& Hussain (2015) consider grit as a precursor to self-efficacy. Their results show that perseverance of effort is a significant and positive predictor of student confidence in their regulatory skills and academic development. Along the same lines, the study by Pasha-Zaidi et al. (2019) confirms the motivating role of grit and its predictive role for self-efficacy and self-regulation levels among university students. 
The main purpose of this cross-sectional study is to explore the association between creative self-efficacy, entrepreneurial self-efficacy and grit among first-year university students. The examination of such variables among first-year students renders an opportunity for higher education institutions to design educational strategies aimed at promoting entrepreneurship throughout the university experience. Self-efficacy and grit are considered as relevant factors in entrepreneurship, and the development of entrepreneurial competence is a common objective of European educational policy (European Union, 2019). Nonetheless, there is limited information regarding the relationship between creative self-efficacy, entrepreneurial self-efficacy and grit.

\section{Methods}

Participants were first-year university students enrolled in degree programs in two broad fields (technical and social sciences) at Mondragon Unibertsitatea and Florida Universitària (Spain). Data collection was carried out at the beginning of the academic years 2018-19, 2019-20 and 2020-21. Students participated in the present study on a voluntary basis. The total sample was 1,958 people, $49 \%$ men and $50 \%$ women. The mean age of women was $18.32(\mathrm{DT}=1.74)$ and that of men was $18.65(\mathrm{DT}=2.03)$.

\subsection{Instruments}

Grit-S Scale (Grit-S, Spanish adaptation by Arco-Tirado et al., (2018); original by Duckworth \& Quinn, (2009). The Short Grit Scale (Grit-S) assesses the capacity to work strenuously toward challenges, maintaining interest and effort over years in order to achieve long-term goals. It has two subscales, Consistency of Interest (CoI) and Perseverance of Effort (Per), both comprising four items which respondents rate using a 5-point Likert-type scale (from 1= "Not like me at all" to 5 = "Very much like me").

Creative Self-Efficacy (CSE) Scale (Tierney \& Farmer, 2002). This instrument measures a person's self-perceived capacity for creative work. It comprises three items that respondents must rate on a 7-point Likert scale ranging from 1 (Totally disagree) to 7 (Totally agree). The instrument has been widely used in educational settings and it has shown good psychometric properties (Hass et al., 2016; Robinson-Morral et al., 2013).

Entrepreneurial Self-Efficacy (ESE) Scale. This was assessed using a series of items developed by Zhao et al., (2005) to measure self-efficacy in relation to specific entrepreneurial tasks. Respondents are asked to indicate on a 5-point Likert scale how confident they are ( $1=$ no confidence; $5=$ complete confidence $)$ in their ability to identify business opportunities, create new products, think creatively and commercialise an idea or new development. 


\section{Results}

Table 1 shows the results of the descriptive analysis.

Table 1. Descriptive statistics.

\begin{tabular}{lcccc}
\hline & CSE & ESE & CoI & Per \\
\hline N & 2135 & 2085 & 1318 & 1311 \\
Mean & 15.40 & 14.45 & 13.28 & 14.69 \\
SD & 2.07 & 2.41 & 2.69 & 2.44 \\
Min & 3.00 & 4.00 & 4.00 & 4.00 \\
Max & 21.00 & 20.00 & 20.00 & 20.00 \\
\hline
\end{tabular}

Bivariate correlations are displayed in Table 2. Significant positive relationships were found between the four variables analysed. The range of correlations (.143 to .500) suggests moderate relationships within the variables; furthermore, the magnitude of the relationships was higher for the self-efficacy variables.

Table 2. Correlational Analysis.

\begin{tabular}{cccccc}
\hline & & CSE & ESE & Per & CoI \\
\hline CSE & Pearson & 1.000 & $0.500^{* *}$ & $0.189^{* *}$ & $0.143^{* *}$ \\
& Sig. & & 0.000 & 0.000 & 0.000 \\
ESE & Pearson & $0.500^{* *}$ & 1.000 & $0.138^{* *}$ & $0.143^{* *}$ \\
& Sig. & 0.000 & & 0.000 & 0.000 \\
\multirow{2}{*}{ Per } & Pearson & $0.189^{* *}$ & $0.138^{* *}$ & 1.000 & $0.339^{* *}$ \\
& Sig. & 0.000 & 0.000 & & 0.000 \\
CoI & Pearson & $0.143^{* *}$ & $0.143^{* *}$ & $0.339^{* *}$ & 1.000 \\
& Sig. & 0.000 & 0.000 & 0.000 & \\
\hline
\end{tabular}

The results of the regression analysis indicated that the models that are able to explain the highest degree of variance are those with creative self-efficacy and entrepreneurial selfefficacy as dependent variables, the models respectively explained $26.4 \%$ and $25.4 \%$ of the total variance. Individual beta coefficients for all models are reported in Table 3. 
Table 3. Regression coefficients.

\begin{tabular}{lccccccccc}
\hline & \multicolumn{2}{c}{ CSE } & \multicolumn{2}{c}{ ESE } & \multicolumn{2}{c}{ Per } & \multicolumn{2}{c}{ CoI } \\
& Std $\beta$ & Sig & Std $\beta$ & Sig & Std $\beta$ & Sig & Std $\beta$ & Sig \\
& & & & & & & & \\
\hline CSE & & & 0.419 & 0 & 0.096 & 0.000 & 0.030 & 0.137 \\
ESE & 0.551 & 0 & & & 0.033 & 0.207 & 0.057 & 0.014 \\
Per & 0.152 & 0 & 0.039 & 0.207 & & & 0.281 & 0 \\
CoI & 0.059 & 0.137 & 0.085 & 0.014 & 0.347 & 0 & & \\
\hline
\end{tabular}

\section{Discussion}

In this study, a positive and strong relationship has been found between student creative and entrepreneurial self-efficacy, which is not unexpected given the importance of creativity in entrepreneurship (Smith et al., 2016). Moreover, this result tends to support previous findings that indicate that multiple self-efficacy beliefs account for anticipatory entrepreneurial cognitions (Schlaegel \& Koenig, 2013). With respect to grit and selfefficacy beliefs, a positive but weak relationship has been found. The results of the regression analysis provide further information and seem to suggest that grit is a precursor to creative and entrepreneurial self-efficacy. This result is consistent with previous studies showing the predictive role of grit for general self-efficacy levels among university studies (Pasha-Zaidi et al., 2019; Wolters \& Hussain, 2015). However, these studies measured selfefficacy at the domain-general level and not in the context of entrepreneurship. In this context, the results of this study seem to confirm the role that grit can play as a facilitator of entrepreneurial action (Salisu et al., 2020), by means of a positive, albeit weak, influence on creative and entrepreneurial self-efficacy. Nevertheless, in view of this weak relationship and the limited information in existence regarding the malleability of grit (Wolters \& Hussain, 2015), it is suggested that interventions to improve students' creative and entrepreneurial identity should be directed towards developing their self-efficacy through the different pathways considered in social cognitive theory.

With regards to the research limitations, more information regarding the different learning contexts developed in each of the universities, together with intersectional approaches contemplating students' gender identities, ethnic culture and socioeconomic variables could provide critical insights on how to nurture entrepreneurial self-perceptions across all students. In addition, the sample was recruited from two Spanish universities, additional research is necessary to explore the external validity of the presented findings with regard to other countries and universities. Nonetheless, this study has shed further light on the 
relationship between grit and self-efficacy. Moreover, the finding of the positive relationship between creative and entrepreneurial self-efficacy has important implications as it renders an opportunity to develop informed interventions directed towards improving student entrepreneurial behaviours. In this regard, the importance of cultivating creativity in educational institutions is highlighted. Cultivating creativity, in addition to being a key objective of contemporary education (Alvarez-Huerta et al., 2021), seems to have a positive influence on the entrepreneurial development of students. In relation to this, further exploration of the pedagogical practices that might help foster creativity would have important practical implications, in light of the results.

\section{References}

Alvarez-Huerta, P., Muela, A., \& Larrea, I. (2021). Student engagement and creative confidence beliefs in higher education. Thinking Skills and Creativity, 40 (100821). https://doi.org/10.1016/j.tsc.2021.100821

Arco-Tirado, J. L., Fernández-Martín, F. D., \& Hoyle, R. H. (2018). Development and validation of a Spanish version of the Grit-S Scale. Frontiers in Psychology, 9 (Feb), 17. https://doi.org/10.3389/fpsyg.2018.00096

Bandura, A. (1997). Self-efficacy: the exercise of control. W.H. Freeman and Company.

Bandura, A. (2006). Guide for constructing self-efficacy scales. Self-Efficacy Beliefs of Adolescents, 307-337. https://doi.org/10.1017/CBO9781107415324.004

Barba-Sánchez, V., \& Atienza-Sahuquillo, C. (2018). Entrepreneurial intention among engineering students: The role of entrepreneurship education. Europ Res on Manag and Bus Econ, 24(1), 53-61. https://doi.org/10.1016/j.iedeen.2017.04.001

Duckworth, A. L., Peterson, C., Matthews, M. D., \& Kelly, D. R. (2007). Grit: Perseverance and Passion for Long-Term Goals. Journal of Personality and Social Psychology, 92(6), 1087-1101. https://doi.org/10.1037/0022-3514.92.6.1087

Duckworth, A., \& Quinn, P. D. (2009). Development and Validation of the Short Grit Scale. Article in Journal of Personality Assessment, 91(2), 166-174. https://doi.org/10.1080/00223890802634290

Etemad, H. (2020). Managing uncertain consequences of a global crisis: SMEs encountering adversities, losses, and new opportunities. Journal of International Entrepreneurship, 18(2), 125-144. https://doi.org/10.1007/s10843-020-00279-z

European Union. (2019). Key Competences for Lifelong Learning. https://doi.org/10.2766/291008

Fuller, B., Liu, Y., Bajaba, S., Marler, L. E., \& Pratt, J. (2018). Examining how the personality, self-efficacy, and anticipatory cognitions of potential entrepreneurs shape their entrepreneurial intentions. Personality and Individual Differences, 125(December 2017), 120-125. https://doi.org/10.1016/j.paid.2018.01.005

Gielnik, M. M., Bledow, R., \& Stark, M. S. (2020). A dynamic account of self-efficacy in entrepreneurship. Journal of Applied Psychology, 105(5), 487-505. https://doi.org/10.1037/ap10000451 
Hass, R. W., Katz-Buonincontro, J., \& Reiter-Palmon, R. (2016). Disentangling creative mindsets from creative self-efficacy and creative identity: Do people hold fixed and growth theories of creativity. Psychology of Aesthetics, Creativity, and the Arts, 10(4), 436-446. https://doi.org/10.1037/aca0000081

Lopez-Ñunez, M. I., Rubio-Valdehita, S., \& Aparicio-Garcia, E. M. (2020). Are entrepreneurs born or made? The influence of personality. Personality and Individual Difference, 154, 109699. https://doi.org/10.1016/j.paid.2019.109699

Newman, A., Obschonka, M., Schwarz, S., Cohen, M., \& Nielsen, I. (2018). Entrepreneurial self-efficacy: A systematic review of the literature on its antecedents and outcomes, and an agenda for future research. Journal of Vocational Behavior, 110(B), 403-419. https://doi.org/10.1016/j.jvb.2018.05.012

Pasha-Zaidi, N., Afari, E., Sevi, B., Urganci, B., \& Durham, J. (2019). Responsibility of learning: a cross-cultural examination of the relationship of grit, motivational belief and self-regulation among college students in the US, UAE and Turkey. Learning Environments Research, 22(1), 83-100. https://doi.org/10.1007/s10984-018-9268-y

Ribeiro-Soriano, D. (2017). Small business and entrepreneurship: their role in economic and social development. Entrepreneurship and Regional Development, 29(1-2), 1-3. https://doi.org/10.1080/08985626.2016.1255438

Robinson-Morral, E. J., Reiter-Palmon, R., \& Kaufman, J. C. (2013). The interactive effects of self-perceptions and job requirements on creative problem solving. Journal of Creative Behavior, 47(3), 200-214. https://doi.org/10.1002/jocb.31

Salisu, I., Hashim, N., Mashi, M. S., \& Aliyu, H. G. (2020). Perseverance of effort and consistency of interest for entrepreneurial career success: Does resilience matter? Journal of Entrepreneurship in Emerging Economies, 12(2), 279-304. https://doi.org/10.1108/JEEE-02-2019-0025

Schlaegel, C., \& Koenig, M. (2013). Determinants of Entrepreneurial Intent: A MetaAnalytic Test and Integration of Competing Models. Entrepreneurship Theory and Practice, 38(2), 1042-2587. https://doi.org/10.1111/etap.12087

Smith, R. M., Sardeshmukh, S. R., \& Combs, G. M. (2016). Understanding gender, creativity, and entrepreneurial intentions. Education and Training, 58(3), 263-282. https://doi.org/10.1108/ET-06-2015-0044

Stajkovic, A. D., Bandura, A., Locke, E. A., Lee, D., \& Sergent, K. (2018). Test of three conceptual models of influence of the big five personality traits and self-efficacy on academic performance: A meta-analytic path-analysis. Personality and Individual Differences, 120 (Sept. 2017), 238-245. https://doi.org/10.1016/j.paid.2017.08.014

Tierney, P., \& Farmer, S. M. (2002). Self-efficacy: Its potential antecedents and relationship to creative performance. Academy of Management Journal, 45(6), 1137 1148. https://doi.org/10.2307/3069429

Usher, E. L., Li, C. R., Butz, A. R., \& Rojas, J. P. (2019). Perseverant grit and self-efficacy: Are both essential for children's academic success? Journal of Educational Psychology, 111(5), 877-926. https://doi.org/10.1037/edu0000324

Wolters, C. A., \& Hussain, M. (2015). Investigating grit and its relations with college students' self-regulated learning and academic achievement. Metacognition and Learning, 10(3), 293-311. https://doi.org/10.1007/s11409-014-9128-9 
Zhao, H., Hills, G. E., \& Seibert, S. E. (2005). The mediating role of self-efficacy in the development of entrepreneurial intentions. Journal of Applied Psychology, 90(6), 12651272. https://doi.org/10.1037/0021-9010.90.6.1265 